\title{
ОСОБЛИВОСТІ МЕДСЕСТРИНСЬКОГО ДОГЛЯДУ ЗА ПАЛІАТИВНИМИ ПАЦІЄНТАМИ ОДЕСЬКОГО ОБЛАСНОГО ЦЕНТРУ СОЦІАЛЬНО ЗНАЧУЩИХ ХВОРОБ
}

\author{
К. М. Слободенюк ${ }^{1}$ А. О. Боб², Н. О. Єрмакова 3 , А. В. Гуцол ${ }^{4}$ \\ ${ }^{1}$ КУ «Одеський обласний протитуберкульозний диспансер» \\ ${ }^{2} Д В Н 3$ «Тернопільський державний медичний університет \\ імені І. Я. Горбачевського МОЗ Украӥни" \\ ${ }^{3}$ Комунальне некомериійне підприємство "Одеський обласний иентр \\ соціально значущих хвороб» Одеської обласної ради \\ ${ }^{4}$ Одеське об'єднане медичне училище
}

\begin{abstract}
Сестринський персонал відіграє ключову роль в організації паліативної допомоги хворим на ВІЛ/СНІД та туберкульоз. Паліативна допомога є цілісним підходом, що складається з медичного, соціального, психологічного та духовного компонентів. Медсестра-ключова особа в оточенні пацієнта, яка забезпечує належну медичну допомогу, кваліфікований догляд та психологічну підтримку паліативним пацієнтам.
\end{abstract}

\section{PECULIARITIES OF NURSING CARE FOR PALLIATIVE PATIENTS IN ODESA REGIONAL CENTER OF SOCIALLY DANGEROUS DISEASES}

\author{
K. M. Slobodenyuk ${ }^{1}$, A. O. Bob ${ }^{2}$, N. O. Ermakova ${ }^{3}$, A. V. Hutsol ${ }^{4}$ \\ ${ }^{1}$ Odesa Regional Antituberculosis Dispensary \\ ${ }^{2}$ I. Horbachevsky Ternopil State Medical University \\ ${ }^{3}$ Communal nonprofit enterprise "Odesa Regional Center for Socially Dangerous Diseases" \\ Odesa Regional Council \\ ${ }^{4}$ Odesa Incorporated Medical Secondary School
}

Nursing staff play a key role in the organization of palliative care for people living with HIV/AIDS and tuberculosis. Palliative care is a holistic approach, consisting of a medical, social, psychological and spiritual component. A nurse is the key person in the environment of the patient who provides proper medical care, qualified assessment and psychological support to palliative patients.

Вступ. Туберкульоз - це одне з найпоширеніших інфекційних захворювань в світі, його діагностують у 2 млрд людей та 3 млн щороку помирають. Туберкульоз - одна з найнебезпечніших і опортуністичних інфекцій в світі, що загрожують ВІЛ-інфікованим людям із низьким імунним статусом. Протидія ВІЛ-інфекції/ СНІДу залишається одним із пріоритетних завдань держави на сьогодні.

Зважаючи на той факт, що кількість померлих від СНІДу щорічно в Україні збільшується, потреба в паліативній допомозі (ПД) цій категорії осіб $\epsilon$ надзвичайно гострою. За даними «Українського центру контролю за соціально небезпечними хворобами Міністерства охорони здоров'я України», у 14 регіо-

(с К. М. Слободенюк, А. О. Боб, Н. О. Єрмакова, А. В. Гуцол, 2019 нах нашої держави, у тому числі в Одеській області, спостерігають підвищення регіональних показників смертності від СНІДу порівняно з відповідними показниками минулого року [2]. Окрім туберкульозу і СНІДу, великою проблемою $є$ хіміорезистентний туберкульоз. Встановлено зв'язок між «полірезистентною формою» туберкульозу та ВІЛ, спеціалісти ВООЗ стверджують, що люди, які живуть з ВІЛ, удвічі вірогідніше отримають саме цю тяжку форму туберкульозу.

Нормативними документами МОЗ України передбачено, що ПД пацієнтам, хворим на туберкульоз та ВІЛ-інфекцію/СНІД, надають у відповідних спеціалізованих лікувально-профілактичних закладах [1]. Одеський обласний центр соціально значущих хвороб створений у березні 2018 р. у результаті об'єднання 
обласної протитуберкульозної служби і центра з профілактики та боротьби зі СНІДом. Центр розрахований на 720 ліжок (2 поліклінічних та 9 стаціонарних відділень). Паліативне відділення центру, яке розташоване у місті Білгород-Дністровський Одеської області, розраховане на 80 ліжок.

Мета роботи: проаналізувати потребу в паліативній допомозі хворим на хронічні інфекційні захворювання, особливо на ВІЛ/СНІД та туберкульоз в Одеській області.

Основна частина. Більшість хворих із ВІЛ/СНІДом та туберкульозною інфекцією потребуватиме ПД і щороку кількість їх постійно збільшується. Міжнародна асоціація лікарів із проблем ВІЛ/СНІДу серед учасників паліативної допомоги хворим на ВІЛ/СНІД та туберкульоз вказує на першому місці медичних сестер, що є абсолютно закономірним на наш погляд [5].

ПД є цілісним підходом, що складається з медичного, соціального, психологічного та духовного компонентів. Медична складова ПД полягає у контролі фізичного стану хворого, симптоматичному лікуванні патологічних проявів хвороби, в тому числі болю, наданні консультацій та навчанні близького оточення навичкам, корисними при догляді за хворим. Соціальний компонент має на меті забезпечити задовільні побутові умови, підтримати соціальне життя, і в той же час допомогти хворим на ВІЛ-інфекцію/СНІД та їх оточенню навчитися самостійно вирішувати соціальні проблеми. Психологічний компонент у рамках ПД вирішує завдання полегшення психологічних станів, пов'язаних із невиліковним захворюванням, подолання стресу, тривожності, депресії хворих, їх оточення, персоналу, залученого до надання Пд. Завданням психологічної підтримки в рамках ПД є нормалізація внутрішнього стану хворого, підтримка психологічної рівноваги між хворим і його оточенням на всіх етапах перебігу захворювання, під час підготовки хворого до лікування, обговорення та підготовка до смерті, допомога близькому оточенню хворого під час і після важкої втрати. Духовна підтримка надається представником релігійної конфесії, за вибором хворого. Важливо, щоб медичні працівники розуміли проблеми, які виникають у людей з ВІЛ, і не лише медичні, але й соціальні, i, особливо, психологічні, вміли забезпечити якісний догляд за пацієнтами зі СНІДом, у тому числі паліативний та хоспісний.

Застосування комбінованої антибіотикотерапії та високоактивної антиретровірусної терапії в останні роки дозволило значно покращити стан хворих та сповільнити прогресування хвороби, однак таке лікування не здатне повністю вилікувати і викликає цілий ряд побічних ефектів. Надання ПД таким хворим зазвичай може супроводжуватися низкою труднощів як медичних (численні інфекції, тривале виснажливе лікування, високий ризик побічних ефектів, велика кількість препаратів), так і психологічних, і соціальних (важкодоступні соціальні прошарки, часто - ВІЛінфіковані статеві партнери, близькі родичі, стигматизація й дискримінація, конфіденційність, великі втрати, страх перед хворобою) [4].

Надання ПД багатопрофільною бригадою при цьому захворюванні $є$ найбільш виправданим, тому що при жодній іншій нозології пацієнти не потребують такої різнобічної клінічної та психологічної допомоги. Паліативна допомога передбачає опіку не лише пацієнта з невиліковним захворюванням, але й членів його родини [3]. Повертаючись до питання захворювань чи причин смерті, неприйнятних для суспільства, варто зазначити, що рідні та близькі пацієнтів зі СНІДом, туберкульозом потребують особливих підходів. У більшості випадків до термінального стану своїх близьких вони приходять через тривалий період боротьби за них, період жалю, гніву, безсилля, сорому, втрати надій. Часто до цього часу вони вже фізично й морально втомлені та спустошені. їхні почуття амбівалентні, а переживання горя може мати риси патологічного характеру [2]. У рідних пацієнтів зі СНІДом може розвиватися передчасне горе, тобто переживання горя заздалегідь, до очікуваної втрати, оскільки це захворювання на сьогодні для широкого загалу залишається невиліковним. Медичні фахівці мають бути обізнаними з такими проявами реакцій i рекомендувати особам із дисфункціональним горем професійну психологічну допомогу. Адже ВІЛ - це не смертельна, а довготривала хронічна хвороба. Часто проблема підбору персоналу для надання Пд хворим на СНІД пов'язана зі страхом інфікування. Тому необхідна грамотна підготовча і роз'яснювальна робота, адже ризик зараження при щоденному догляді та в побуті мало імовірний, і дотримання нескладних правил абсолютно убезпечує осіб, які опікуються ними.

Основною складовою ПД $є$ психологічна готовність спеціалістів із медичною освітою працювати з пацієнтами з туберкульозом, ВІЛ/СНІДом, адже нерідко такі хворі належать до соціально незахищених прошарків населення, зазнають стигматизацій й дискримінації. Зважаючи на цілий ряд особливих психологічних проблем, питанню спілкування та його психологічним 
аспектам при наданні паліативної допомоги пацієнтам, які мають ВІЛ/СНІД, надається саме медичній сестрі.

Діагноз пацієнта з туберкульозом, ВІЛ/СНІДом, як правило, є причиною постійного емоційного напруження, страху та відчаю. 3 усвідомленням тяжкості захворювання пацієнт вступає в якісно нову життєву ситуацію. Хвороба остаточно змінює всі перспективи людського життя, характер орієнтації на майбутнє. Така зміна - одна з найбільших причин зміни емоційного стану паліативних пацієнтів. Майбутнє стає невизначеним, не відповідає сформованим планам і очікуванням. За умов захворювання відмова від професійної діяльності, порушення можливостей самообслуговування та задоволення потреб змінюють психологічний стан хворого. Першим сигналом перебудови $є$ виникнення якісно нового емоційного стану. Розпочинається процес об'єктивної зміни суспільної ролі. Спочатку пацієнт усвідомлює своє нове становище як невиліковно хворого, це відображається безпосередньою емоційною реакцією на ситуацію. Пацієнт стає мовчазний, відчужений, пасивний, відмовляється від спілкування.

Емоційні навантаження, які відчувають пацієнти хоспісу, визначаються насамперед їх особистісними особливостями, а також думками про біль і неминуче завершення життя. Усі пацієнти пов'язують своє відчуття самотності з переживаннями, що зумовлені хворобою та тяжким станом здоров'я. Скарги пацієнтів можна підтвердити даними медсестринського обстеження.

\section{СПИСОК ЛІТЕРАТУРИ}

1. Брацюнь О. П. Вплив міждисциплінарного підходу в наданні паліативної допомоги на якість життя паліативних пацієнтів (на прикладі роботи першого денного хоспісу в Україні) / О. П. Брацюнь, Г. М. Науменко // Реабілітація та паліативна медицина. - 2016. - № 1. - С. 80-83.

2. Вороненко Ю. В. Створення системи паліативної і хоспісної допомоги в умовах реформування охорони здоров'я в Україні: медичні і соціальні аспекти / Ю. В. Вороненко, Ю. І. Губський, А. В. Царенко // Охорона здоров'я і суспільство. - 2014. - № 1 (2). - С. 63-75.

3. Гойда Н. Г. Соціально-медичні аспекти розвитку паліативної та хоспісної допомоги в Україні в умовах
Проведене медсестринське обстеження підтверджує, що високий рівень суб'єктивного відчуття самотності може бути зумовлений порушенням задоволення фундаментальних фізіологічних потреб та обмеженими можливостями.

У цьому випадку важлива роль належить медичній сестрі - вона допоможе пацієнту адаптуватися до ситуації та відновити психологічну рівновагу, навчить пацієнта самодогляду, забезпечить задоволення основних життєво важливих потреб. У такий період медична сестра безпосередньо опікує хворого, втішає його, намагається полегшити його страждання, виконати його побажання. Ця материнська турбота $\in$ сутністю професії медичної сестри, адже медсестринство - це мистецтво турботи про пацієнта [4]. Медсестра - ключова особа в оточенні пацієнта, яка забезпечує належну медичну допомогу, кваліфікований догляд та психологічну підтримку.

Висновки. Забезпечення ПД високої якості пацієнтам із хронічними інфекційними захворюваннями, у тому числі ВІЛ-інфекцією/СНІДом, туберкульозом, повинно бути одним із пріоритетних напрямів розвитку української системи охорони здоров'я. Організація та ефективне функціонування системи ПД хворим із хронічними інфекційними захворюваннями можливі лише за умови якісної підготовки молодших медичних спеціалістів на додипломному та післядипломному рівнях, що ґрунтується на розробці та використанні сучасного науково-методичного забезпечення.

реформування системи охорони здоров'я / Н. Г. Гойда, Ю. І. Губський, А. В. Царенко // Реабілітація та паліативна медицина. - 2015. - № 2. - С. 23-30.

4. Ястремська С. О. Роль медичних сестер у паліативній (хоспісній) допомозі / С. О. Ястремська, О. С. Усинська // Медсестринство. - 2011. - № 3. - С. 4-7.

5. White Paper on standards and norms for hospice and pallianive care in Europe [Electronic resource] / Recommendations from the European Association for Palliative Care. Part I // European Journal of Palliative Care. - 2009. No. 16 (6). - P. 278-289. 